\title{
Pemanfaatan Media Video Animasi dan Permainan Tradisional dalam Bimbingan Belajar Siswa SD Selama Masa Pandemi Covid-19
}

\author{
Maria Silvia Aso ${ }^{*}$, Helena Susanti Anur², Adrianus Nasar ${ }^{3}$ \\ 1,2,3,4,5 Universitas Flores Ende \\ *Corresponding Author: mariasilviaaso@gmail.com
}

\begin{abstract}
Info Artike1 Diterima : 21/08/2021 Direvisi: 09/09/2021 Disetujui: 13/09/2021
Abstract. The purpose of tutoring for the students of SDK Kekandere 2 is to help students understand the material well in the midst of the ongoing Covid-19 pandemic situation. The learning media used during tutoring are animated videos and traditional games as learning methods. The purpose of using animated videos is to make students more enthusiastic about participating in learning and also to increase students' understanding of the material they are learning. Traditional games are used so that students do not get bored easily or students can learn while playing. Besides that, it also helps students to find their own concepts because previously students only got material information from the teacher. And in between learning activities, reading exercises were carried out for students who were not yet fluent in reading. The results of the tutoring carried out can improve students' understanding, students are very enthusiastic about participating in the learning process and students are able to learn to find their own concepts even though they are not perfect. Meanwhile, to read only needs regular practice from students.
\end{abstract}

Keywords: Animated videos, Traditional games, Tutoring, Covid-19

\begin{abstract}
Abstrak. Tujuan dilakukannya bimbingan belajar kepada siswa-siswi SDK Kekandere 2 adalah untuk membantu siswa-siswi untuk memahami materi dengan baik ditengah situasi pandemi Covid-19 yang belum berakhir ini. Media pembelajaran yang digunakan selama bimbingan belajar adalah video animasi dan permainan tradisional sebagai metode pembelajaran. Tujuan dari penggunaan video animasi adalah agar peserta didik lebih antusias mengikuti pembelajaran dan juga meningkatkan pemahaman peserta didik tentang materi yang dipelajarinya. Permainan tradisional digunakan agar siswa tidak mudah bosan atau peserta didik dapat belajar sambil bermain. Selain itu juga membantu peserta didik untuk menemukan konsep sendiri karena sebelumnya siswa hanya mendapatkan informasi materi dari guru saja. Dan disela kegiatan pembelajaran, dilakukan kegiatan latihan membaca kepada siswa-siswi yang belum lancar membaca. Hasil dari bimbingan belajar yang dilakukan dapat meingkatkan pemahaman peserta didik, peserta didik sangat antusias mengikuti proses pembelajaran dan juga peserta didik sudah bisa belajar menemukan konsep sendiri meskipun belum sempurna. Sedangkan untuk membaca hanya perlu latihan rutin dari peserta didik.
\end{abstract}

Kata Kunci: Video animasi, Permainan tradisional, Bimbingan belajar, Covid-19

How to Cite: Aso, M.S., Anur, H.S., \& Nasar, A. (2021). Pemanfaatan Media Video Animasi dan Permainan Tradisional dalam Bimbingan Belajar Siswa SD Selama Masa Pandemi Covid-19. Prima Abdika : Jurnal Pengabdian Masyarakat, 1(3), 98-106. https://doi.org/10.37478/abdika.v1i3.1218 undera Creative Commons Attribution-ShareAlike 4.0 International License.

\section{Pendahuluan}

Kuliah Kerja Nyata (KKN) merupakan salah satu kegiatan wajib dalam dunia pendidikan khususnya pada jenjang perguruan tinggi yang bentuk kegiatannya masuk dalam kategori pengabdian. Pengabdian yang dimaksud adalah pembaktian diri mahasiswa kepada masyarakat. KKN merupakan saah satu program yang dijalankan untuk mewujudkan salah satu tujuan dari Tri Darma Perguruan Tinggi yang terdapat pada poin ke tiga yaitu "Pengabdian Kepada Masyarakat "dengan memanfaatkan ilmu pengetahuan dan teknologi untuk memajukan kesejahteraan masyarakat dan juga mencerdaskan anakanak bangsa. Kegiatan Kuliah Kerja Nyata (KKN) masih sama seperti KKN tahun 2020 yakni secara mandiri dikarenakan kondisi pandemi yang masih meningkat. Akibat dari meningkatnya jumlah pasien Covid, maka pemerintah melakukan pembatasan aktivitas masyarakat untuk mencegah agar Covid 
tidak semakin menyebar luas dengan mengeluarkan aturan PPKM (Pemberlakuan Pembatasan Kegiatan Masyarakat). Menimbang kebijakan pemerintah tersebut, maka pihak kampus memutuskan untuk tetap melaksanakan program KKN tahun 2021 ini secara online/mandiri dengan mengangkat tema "Masyarakat Tangguh dalam Menghadapi Covid 19 Bersama KKN Uniflor".

Merebaknya wabah Covid-19 pada akhir tahun 2019 membawa dampak yang buruk bagi masyarakat di seluruh dunia termasuk Indonesia. Dalam usaha untuk memutuskan mata rantai penyebaran Covid-19 pemerintah Indonesia mengambil kebijakan berupa penerapan sosial distancing dimana segala aktivitas dilakukan dari rumah. Penerapan kebijakan tersebut tentu saja berdampak terhadap seluruh sektor kehidupan salah satunya sektor pendidikan. Kegiatan belajar mengajarpun terpaksa harus dilakukan secara daring/online. Akan tetapi, dari kebijakan tersebut, ada banyak pihak yang belum siap melaksanakan pembelajaran jarak jauh karena keterbatasan perangkat yang menunjang kegiatan pembelajaran jarak jauh tersebut.

Salah satu upaya untuk membantu meningkatkan pemahaman peserta didik adalah dengan bimbingan belajar. Bimbingan belajar merupakan kegiatan yang sangat penting dilakukan untuk membantu peserta didik agar mampu melakukan penyesuaian diri ditengah situasi pandemi seperti saat ini. Menurut Fiah dan Purbaya (2016) bimbingan belajar merupakan bimbingan untuk menemukan cara yang tepat dalam belajar. Hermawan (2012) berpendapat bahwa bimbingan belajar merupakan bantuan yang diberikan kepada peserta didik secara berkesinambungan agar dapat belajar semaksimal mungkin sesuai dengan tingkat kemampuan siswa. Sedangkan Winkel dan Siukardi (2010) berpendapat bahwa bimbingan belajar merupakan proses untuk menemukan cara belajar yang tepat dalam memilih program studi yang sesuai serta untuk mengatasi kesukaran-kesukaran yang timbil dalam bidang pendidikan. Berdasarkan pendapat para ahli tersebut, dapat disimpulakn bahwa bimbingan belajar merupakan suatu upaya yang dilakukan untuk membantuk seseorang menemukan cara yang tepat untuk mendapatkan hasil belajar yang maksimal.

Dalam kegiatan pembelajaran, tidak terlepas dari media dan metode pembelajaran yang akan digunakan untuk meningkatkan antusias siswa untuk mengikuti pembelajaran. Media pembelajaran adalah suatu alat atau sarana yang digunakan untuk berinteraksi dengan peserta didik selama proses pembelajaran untuk memperoleh pengetahuan dan keterampilan dan juga membantu peserta didik untuk mencapai tujuan pembelajaran. Meurut Asyar (2012), media pembelajaran adalah sesuatu yang dapat memberikan pesan dari sumber secara terencana sehingga dapat menciptakan lingkungan belajar yang kondusif dimana proses belajarnya dapat berjalan dengan efektif dan efisien. Munawwarah (2019) berpendapat ahwa media pembelajaran merupakan alat bantu dalam proses pembelajaran atau alat untuk berkomunikasi antara guru dengan siswa selama proses pembelajaran berlangsung. Menurut Sadiman (2008), media pembelajaran adalah segala sesuatu yang dipakai selama proses pembelajaran yang dapat menyampaikan pesan dari pengirim kepada penerima. Berdasarkan uraian pendapat para ahli, maka dapat disimpulkan bahwa media pembelajaran merupakan suaru alat atau sarana yang dipakai selama proses pembelajaran yang dapat 
memberikan pesan kepada peserta didik secara terencana. Contoh media pembelajaran seperti media audio, visual, audio visual, gambar dan masih banyak media pembelajaran lainnya.

Menurut Hurlock dalam Setiawan dan Handayani (2017) usia anak Sekolah Dasar adalah taraf usia bermain. Pada usia-usia ini anak lebih suka bergerak. Desmita dalam Setiawan dan Handayani (2017) berpendapat bahwa anak-anak SD senang bermain, bergerak, bekerja dalam kelompok dan senang melakukan sesuatu yang nyata. Hal tersebut membuat siswa menjadi merasa tidak bebas untuk mengekspresikan kemampuannya karena kebiasaan guru yang masih menerapkan metode ceramah. Akibatnya siswa menjadi mudah bosan mengikuti pembelajaran. Menurut Moch Latif et al. (2019), dalam permainan tradisional terdapat beberapa aspek yang menjadi cirri utama diantaranya rasa tanggung jawab, kerja sama, saling menghormati, disiplin, kerja keras dan saling menolong. Maka sari itu permainan tradisonal sangat menarik untuk diajarkan dalam kegiatan pembelajaran karena dampak dari permaainan tradisional akan positif terhadap minat siswa. Namun, dianjurkan agar guru lebih kreatif untuk meneraapkan permainan tradisional karena harus bisa menyesuaikan kondisi yang ada di lapangan sehingga dapat memperoleh hasil seperti yang diharapkan.Pemanfaatan permainan tradisional juga memberikan perubahan yang baik kepada siswa yang ditunjukan dengan semangat siswa untuk melakukan kegiatan pembelajaran dan juga respon yang diberikan ketika ditanya oleh pelaksana setelah selesai melakukan permainan tradisional.

Sesuai tema yang dipilih, pelaksana KKN Universitas Flores melibatkan diri dilembaga pendidikan yang ada di Desa Kekandere untuk menerapkan pembelajaran yang inovasi berbasis teknologi kepada siswa-siswi yang ada di SDK Kenadere 2.SDK Kekandere 2 merupakan satu-satunya lembaga pendidikan tingkat SD yang ada di desa Kekandere. SDK Kekandere 2 berdiri sejak tanggal 01 Januari tahun 1960. SDK Kekandere 2 termasuk salah satu sekolah yang mengalami kesulitan untuk menerapkan kebijakan untuk melaksanakan kegiatan pembelajaran secara daring/online dikarenakan fasilitas yang menunjang diberlakukan keijakan tersebut kurang mendukung. Maka, dalam menyikapi hal tersebut pihak sekolah mengambil keputusan untuk memberlakukan sistem BDR (Belajar Dari Rumah yaitu siswa-siswi datang ke sekolah hanya untuk mengambil tugas kemudian mengerjakannya di rumah dan setelh itu kembali ke sekolah untuk mengumpulkan tugas sesuai dengan waktu yang ditentukan oleh pihak sekolah.

Berdasarkan hasil wawancara yang dilakukan terhadap Wakil kepala Sekolah, hasil belajar yang diperoleh siswa selama masa pandemi mengalami penurunan dibandingkan sebelum pandemi. Hal tersebut menunjukan bahwa langkah yang diambil oleh pihak sekolah untuk memberlakukan sistem BDR kurang efektif. Maka dari itu, pada tahun ajaran baru yaitu 2021/2022, pihak sekolah memberlakukan sekolah sistem shift yaitu untuk kelas 1,3 dan 5 mendapatkan jadwal hari Selasa dan Kamis sedangkan kelas 2, 4 dan 6 mendapatkan jadwal hari Senin, Rabu dan Jumad dengan jam pelajaran disekolah hanya 3 jam. Penerapan sistem shift tersebut juga belum terlalu berpengaruh baik terhadap siswa karena guru kesulitan membagi waktu untuk menjelaskan materi dan pemberian tugas dengan waktu selama disekolah yang hanya sebentar. Kemudian dalam menjelaskan materi guru juga masih menerapkan metode ceramah sehingga peserta didik mudah jenuh 
untuk mendengarkan pelajaran sehingga menurunkan minat siswa untuk mengikuti pembelajaran yang kemudian juga berdampak terhadap hasil belajar siswa. Selain kedua masalah diatas ada juga peserta didik kelas III dan kelas IV yang belum lancar membaca.

Berdasarkan uraian permasalahan di atas, sebagai bentuk pengabdian kepada masyarakat mahasiswa Universitas Flores akan mendarmabaktikan diri sesuai dengan bidang ilmu yang dikuasai yaitu bidang pendidikan, Tim KKN menawarkan untuk melakukan kegiatan bimbingan belajar kepada peserta didik kelas III dan kelas IV SDK Kekandere 2 dengan memanfaatkan video animasi sebagai media pembelajaran dan permainan tradisional sebagai metode pembelajaran. Disela kegiatan pembelajaran akan dilakukan latihan membaca bagi peserta didik yang belum lancar membaca.

\section{Metode Pelaksanaan}

Kegiatan bimbingan belajar dilakukan selama waktu KKN yang ditentukan oleh pihak kampus yaitu mulai tanggal 2-30 Agustus. Akan tetapi, karena pihak sekolah memberlakukan system shift, maka pelaksana memanfaatkan hari libur peserta didik kelas III dan IV yaitu 2 kali bimbingan dalam satu minggu. Akan tetapi sebelum memberikan bimbingan belajar, pelaksana menggunakan metode wawancara untuk memperoleh informasi tentang sekolah dan juga mengetahui permasalahan yang ada untuk diberikan solusi atau jalan keluar.

Dari permasalahan yang ditemukan, pelaksana melakukan bimbingan belajar dengan metode pengajaran. Media yang digunakan selama melakukan bimbingan belajar adalah video animasi dengan memanfaatkan teknologi berupa handphone dan permainan tradisional adalah metode pembelajaran yang dipakai selama bimbingan belajar. .

Adapun tahap-tahap pelaksanaan dari metode pengajaran yaitu kegiatan pembuka yaitu memberi salam, menyiapkan siswa untuk mengikuti pembelajaran dan menyampaikan tujuan pembelajaran yang akan dilaksanakan. Setelah kegiatan pembuka masuk ke kegiatan inti terdiri atas siswa melakukan permainan tradisional (Paneke atau Petak Umpet, Rako Ne Meo atau Anjing dan Kucing dan Inggo atau Hadang). Satu tema pembelajaran siswa melakukan satu permainan tradisional. Selesai melakukan permainan siswa istirahat sejenak selanjutnya menanyakan siswa tentang keterkaitan permainan dengan materi yang akan dipejari. Lalu menayangkan video animasi melalui handphone setelah itu bertanya kepada siswa apa yang mereka pahami dari video yang ditayangkan. Kemudian memberikan penegasan dan mencoba tingkat pemahaman siswa dengan memberikan pertanyaan lisan mengenai materi yang baru dibahas. Terakhir kegiatan penutup meliputi pemberian tugas dan doa sebelum pulang.

\section{Hasil dan Pembahasan}

Berdasarkan latar belakang masalah yang dipaparkan, ada beberapa pion permasalahan yang diambil antaralain (1) keadaan pandemi yang membuat sekolah menetapkan sistem shift tidak memberikan pengaruh terhadap pemahaman siswaakan materi. (2) Metode ceramah yang digunakan membuat siswa-siswi mudah bosan mengikuti pembelajaran. (3) Ada beberapa peserta didik yang belum lancar membaca. 
Berkaitan dengan permasalahan tersebut, pelaksana KKN membuat salah satu program kerja yaitu bimbingan belajar atau bimbel. Bimbingan belajar dilaksanakan di kantor desa Kekandere, Desa Kekandere Kecamatan Nangapanda Kabupaten Ende selama depalan kali yaitu enam kali dengan siswa-siswi kelas IV dan dua kali dengan siswa-siswi kelas III. Kegiatan bimbingan belajar dilaksanakan dengan tetap mematuhi protokol kesehatan dimana siswa-siswi dan juga pelaksana menggunakan masker dan sebelum belajar memakai handsanitizer.

Kegiatan bimbingan belajar dimulai dengan menyapa siswa dan memberikan kesempatan kepada salah satu siswa untuk berdoa. Agar siswa lebih antusias mengkuti pembelajaran, selesai menyampaikan tujuan pembelajaran siswa-siswi melakukan permainan tradisional yang ada di daerah tersebut. Permainan yang dipilih merupakan jenis permainan yang masih ada kaitannya dengan materi yang akan diajarkan. Selesai melakukan permainan siswa-siswi beristirahat lalu pelaksana bertanya tentang apa yang mereka pahami tentang permainan tersebut dan apakah ada kaitannya dengan materi. Dan setelah itu siswa-siswi diberi kesempatan untuk menonton video animasi yang sudah disiapkan dengan menggunakan handphone pelaksana.

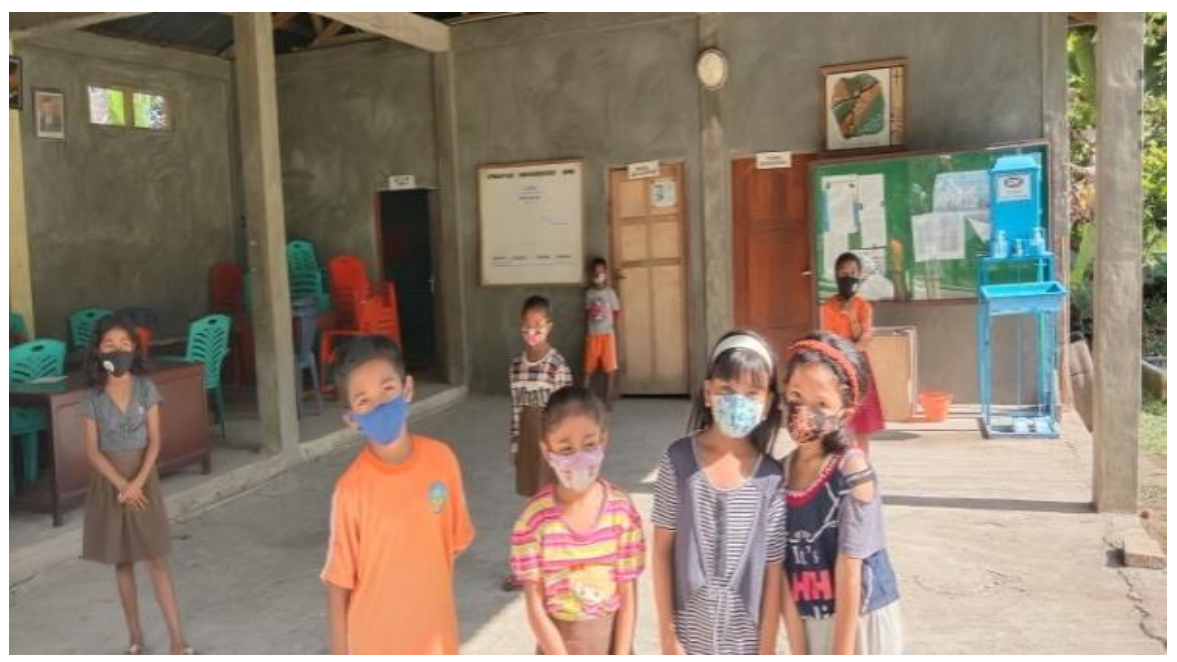

Gambar 1. Para Siswa SD di Desa Kekandere

Berikut dijelskan pelaksanaan bimbingan belajar kepada siswa-siswi SDK Kekandere 2 di masa pandemi.

Tabel 1. Pelaksanaan Bimbingan Belajar

\begin{tabular}{cll}
\hline Waktu & \multicolumn{1}{c}{ Kegiatan } & Pelaksana \\
\hline 12 & Bimbingan belajar kepada siswa/i SDK Kekandere 2 kelas IV yang & Maria Silvia \\
Agustus & berdomisili di Dusun Ndadho sebanyak 4 orang. Materi yang & Aso \\
2021 & dipejari pada pertemuan pertama yaitu "Bunyi". Kegiatan dimulai & \\
& dengan menyapa siswa, menanyakan kabar siswa dan menyuruh & Susanti \\
& salah satu siswa untuk memimpin doa. Setelah itu menanyakan & Anur \\
& siswa tentang alat musik yang sering mereka lihat. Setelah siswa & \\
& menjawab, pelaksana menyampaikan tujuan pembelajaran. & \\
& Kegiatan inti dimulai dengan menayangkan video animasi tentang & \\
& bunyi yang ada di YouTube dengan menggunakan handphone, & \\
& selesai menonton pelaksana menanyakan kepada siswa apa yang & \\
& mereka pahami dari video yang baru ditonton. Setelah itu & \\
& pelaksana memberikan penegasan kembali lalu mencoba & \\
pemahaman siswa dengan memberikan pertanyaan lisan. Setelah &
\end{tabular}


itu pelaksana membuat kesimpulan dan terakhit menyuruh salah satu siswa memimpin doa pulang.

14 Bimbingan belajar kepada siswa/i SDK Kekandere 2 kelas IV yang

Agustus berdomisili di Dusun Puu Jambu sebanyak 7 orang. Materi yang 2021 dipejari adalah "Bunyi" dan media pembelajaran yang digunakanpun masih sama dengan media yang digunakan pada pertemuan sebelumnya.

18 Melakukan bimbingan belajar kepada siswa/I SDK Kekandere 2 Agustus kelas IV dengan membahas materi tentang Indera Pendengaran 2021 (Telinga). Pada bimbingan belajar kali ini adalah memanfaatkan permainan local yang bernama "Paneke" atau Petak Umpet. Kegiatan dimulai dengan menyapa siswa, menanyakan kabar siswa dan menyuruh salah satu siswa untuk memimpin doa. Setelah itu menanyakan siswa tentang alat musik yang sering mereka lihat. Setelah siswa menjawab, pelaksana menyampaikan tujuan pembelajaran. Kegiatan inti dimulai dengan siswa-siswi melakukan permainan Paneke atau Petak Umpet. Alasan penggunaan permainan tersebut adalah cara bermainnya yaitu siswa yang pergi bersembunyi menyampaikan informasi dengan memukul botol bir sebagai tanda bahwa mereka sudah bersembunyi dan orang yang menutup mata siap mencari. Keterkaitannya dengan materi adalah ketika memukul botol bir, bunyi akan sampai ke telinga manusia. Selesai melakukan perainan, siswa-siswi beristirahat lalu pelaksana bertanya keterkaitan materi dengan permainan yang dilakukan. Kemudian pelaksana menayangkan video animasi tentang indera pendengaran (telinga) yang ada di YouTube dengan menggunakan handphone, selesai menonton pelaksana menanyakan kepada siswa apa yang mereka pahami dari video yang baru ditonton. Setelah itu pelaksana memberikan penegasan kembali lalu mencoba pemahaman siswa dengan memberikan pertanyaan lisan. Setelah itu pelaksana membuat kesimpulan dan terakhit menyuruh salah satu siswa memimpin doa pulang.

19 Melakukan bimbingan belajar kepada siswa/I SDK Kekandere

Agustus 2021

23

Agustus

2021 kelas IV dengan materi yang dibahas adalah bagian-bagian telinga. Media pembelajaran yang digunakan pada pembelajaran ini adalah dengan menayangkan video animasi tentang bagianbagian telinga beserta fungsinya. Tahap-tahap kegiatannya hampir sama dengan pertemuan sebelumnya karena masih dalam satu tema. Akan tetapi pada pertemuan ini pelaksana juga menyediakan media tambahan berupa gambar dari bagian-bagian telinga dilengkapi dengan keterangan sehingga siswa bisa lebih paham. Pertemuan ini juga siswa dilatih membaca keterangan dari gambar sehingga latihan membaca bisa sejalan dengan kegiatan belajar.

Melakukan bimbingan belajar kepada siswa/I SDK Kekandere kelas III yang membahas materi tentang cirri-ciri makluk hidup. Kegiatan pembelajaran dimulai dengan menyapa siswa, lalu menyuruh salah satu siswa memimpin doa. Setelah itumenanyakan kesiapan siswa untuk mengikuti pembelajaran. Sebelum masuk di kegiatan inti, siswa-siswi disuruh menyanyi. Setelah siswa menonton video yang sudah disiapkan. Selesai menonton, pelaksana bertanya tentang apa yang sudah ditonton

Melakukan bimbingan belajar kepada siswa/I kelas IV yang membahas materi tentang energy. Media pembelajaran yang digunakan adalah siswa/I melakukan permainan local "Rako ne
Maria Silvia

Aso

Helena

Susanti

Anur

Maria Silvia

Aso

Helena

Susanti

Anur

Maria Silvia Aso

Helena

Susanti

Anur

Maria Silvia Aso

Maria Silvia Aso 
Meo “ atau bermain kejar-kejaran. Selain itu pelaksana juga menggunakan video animasi sebagai media pembelajaran.

25 Melakukan bimbingan belajar kepada siswa/I SDK Kekandere 2

Agustus kelas III yang membahas materi tentang pertumbuhan dan

perkembangan pada manusia. Media yang digunakan berupa video animasi tentang bayi semenjak lahir sampai tumbuh dewasa. Selain itu untuk mengetahui bakat dan juga untuk meningkatkan aktivitas siswa, pelaksana meberikan kesempatan kepada siswa yang bisa menggambar untuk menggambar manusia dari bayi hingga dewasa.

26 Melakukan bimbingan belajar kepada siswa/I SDK Kekandere Agustus kelas IV yang membahas materi tentang energy matahari dan 2021 energy listrik. Kegiatan pembelajaran diawali dengan siswa/i melakukan permainan "Inggo" atau bermain Hadang. Kemudian pelaksana menanyakan keterkaitan dari materi dengan permainan. Setelah menjelaskan secara umum materi, pelaksana menyuruh siswa-siswi untuk menonton video animasi yang ditayangkan. Dan terakhir pelaksana melakukan tes lisan materi

Maria Silvia Aso

Helena Susanti

Anur

Maria Silvia Aso

Helena

Susanti

Anur yang diajarkan.

Berdasarkan uraian di atas kegiatan bimbingan belajar berfokus pada mata pelajaran IPA. Materi yang diajarkan diseuaikan dengan materi ajar semester 1 dan sesuai dengan tema yang diambil dari buku panduan di sekolah. Untuk siswa-siswi kelas IV pelaksana membahas materi untuk tema 1 tentang "Bunyi" dan tema 2 tentang "Energi" yang dilaksanakan sebnayak enam kali bimbingan belajar. Sedangkan untuk siswa-siswi kelas III hanya membahas satu tema yaitu "Makluk Hidup" yang dilakukan sebnyak dua kali bimbingan belajar. Untuk meningkatkan antusias belajar siswa pelaksana memanfaatkan video animasi dan juga menggunakan permainan tradisional sebagai metode pembelajaran sehingga siswa tidak mudah bosan dengan pelajaran yang dilakukan. Selain itu dengan permainan tradisional, pelaksana menyusun strategi pembelajaran yang bisa melatih siswa untuk bisa menemukan konsep sendiri karena di sekolah hanya menerapkan metode ceramah sehingga siswa hanya mengharapakn infromasi dari guru dan tidak bisa menemukan konsep.

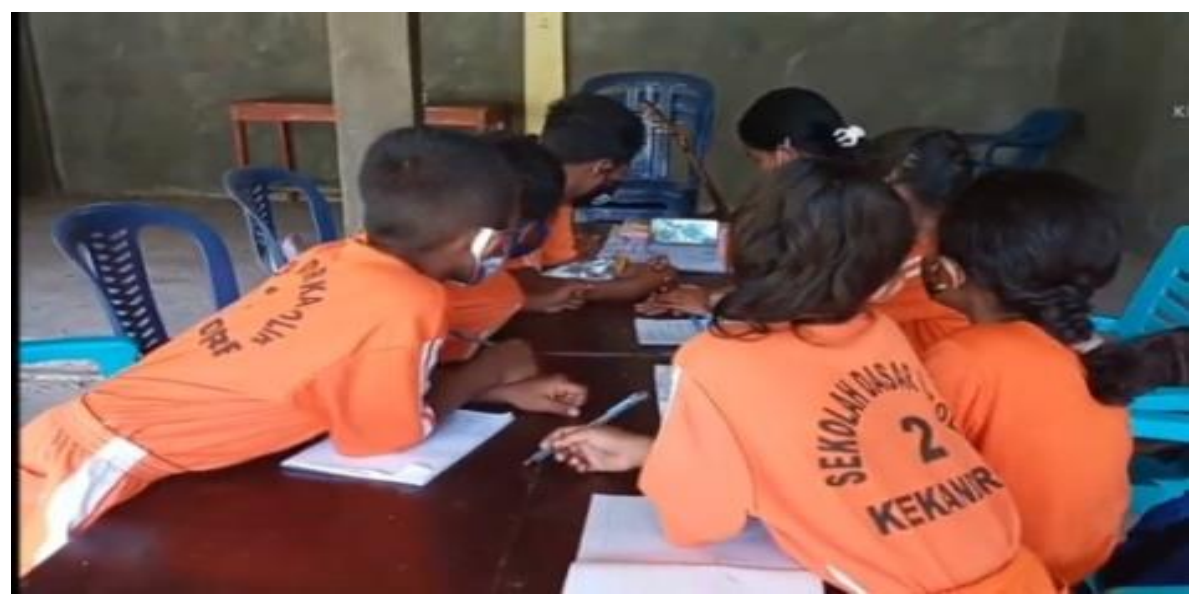

Gambar 2. Siswa siswi menonton video animasi

Kegiatan latihan mebaca kepada siswa-siswi yang belum lancar membaca dilaksanakan sejalan dengan pelaksanaan kegiatan bimbingan belajar.Jadi, selain melatih membaca siswa juga mengingat materi yang dibacanya karena 
siswa-siswi sudah bisa mengenali huruf jadi tidak perlu melakukan latihan dari abjad. Untuk hasil yang dicapai sudah baik, hanya perlu latihan yang rutin agar siswa-siswi dapat lebih lancar membaca..

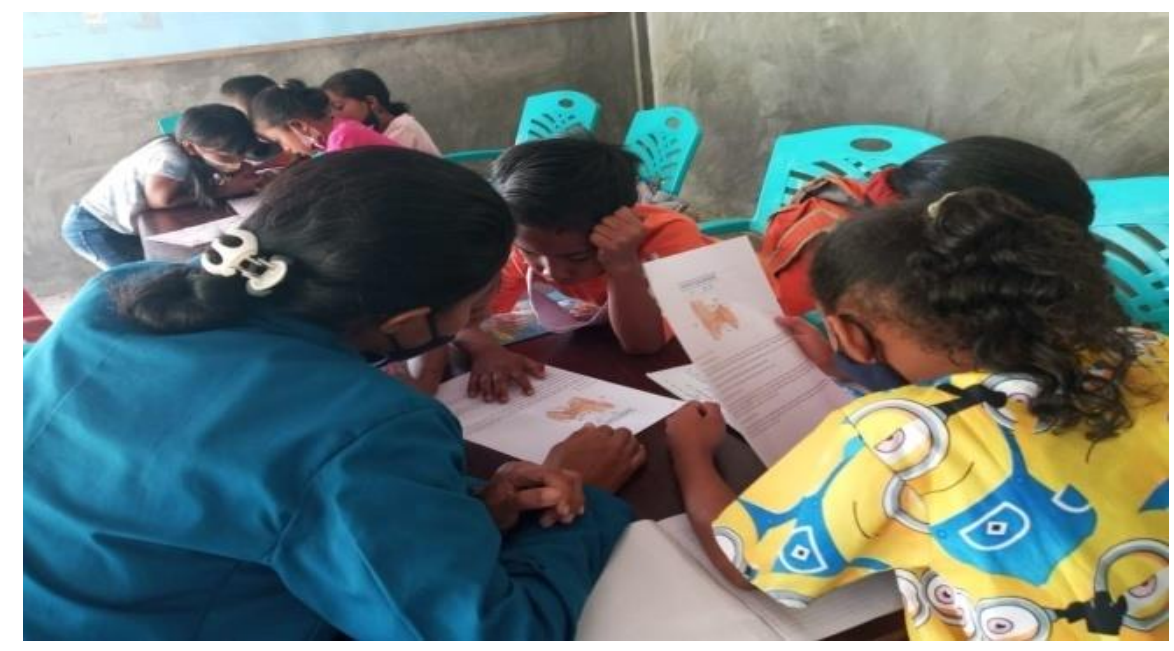

Gambar 3. Siswa siswi melakukan kegiatan latiha membaca

Kegiatan latihan membaca kepada siswa-siswi yang belum lancar dilaksanakan sejalan dengan pelaksanaan kegiatan bimbingan belajar.Jadi, selain melatih membaca siswa juga mengingat materi yang dibacanya karena siswa-siswi sudah bisa mengenali huruf jadi tidak perlu melakukan latihan dari abjad. Untuk hasil yang dicapai sudah baik, hanya perlu latihan yang rutin agar siswa-siswi dapat lebih lancar membaca.

Ada beberapa luaran yang dihasilakn dari program bimbingan belajar antara lain siswa-siswi dapat memahami materi yang diajarkan dengan baik. Hal ini dibuktikan ketika pelaksana bertanya pada saat akhir pembelajaran, siswa-siswi bisa menjawabnya dengan baik. Penggunaan media video animasi dan metode pembelajaran berupa permainan tradisional juga mendapatkan hasil yang memuaskan. Hal ini terbukti dengan antusias siswa-siswi selama proses pembelajaran yang sangat baik dan hampir semua siswa-siswi mengikuti kegiatan bimbingan belajar yang dilakukan pelaksana. Selain itu, siswa-siswi juga mengakui bahwa sangat suka dengan bimbingan belajar yang dilakukan karena di sekolah hanya mendengarkan guru yang menjelaskan jadi mudah merasa bosan. Selain antusias siswa, siswa-siswi juga sudah bisa menemukan konsep sendiri dari beberapa permainan tradisional yang digunakan meskipun belum sempurna sesuai konsep aslinya. Akan tetapi siswa-siswi sudah bisa belajar untuk menemukan konsep sendiri. Dan yang terakhir untuk latihan membaca hasilnya sudah baik tapi belum cukup dengan latihan dari pelaksana saja, perlu latihan rutin dari siswa-siswi baik dengan bimbingan guru ataupun orangtua agar bisa mendapatkan hasil yang lebih baik lagi.

\section{Simpulan dan Tindak Lanjut}

Berdasarkan uraian di atas maka dapat disimpulkan bahwa kegiatan bimbingan belajar di masa pandemi sangat dibutuhkan siswa SDK Kekandere 2 agar dapat meningkatkan pemahaman siswa terhadap materi yang diberikan. Penggunaan media video animasi juga dapat meningkatkan antusias siswa selama mengikuti kegiatan pembelajaran. Selain itu, metode 
permainan juga sangat menarik untuk digunakan kepada anak usia Sekolah Dasar sehingga selain siswa tidak bosan juga dapat melatih kemampuan siswa untuk bisa menemukan konsep sendiri.

\section{Daftar Pustaka}

Rayandra Asyar. (2012). Kreatif Mengembangkan Media Pembelajran. Jakarta: Gaung Persada Press.

Hermawan. (2012). Bimbingan Belajar dab Remedial Akademik. Surakarta: UNS Press.

Latif, dkk, (2019).Pengaruh Permainan Tradisional Terhadap Minat Siswa di SMA 1 Cikembar.Activity Journal (PAJU), 1(1), 82-90

Yektyastuti, dkk (2021) Bimbingan Belajar Siswa Sekolah Dasar di Masa Pandemi Covid-19. Jurnal Pengabdian pada Masyarakat, 2(1), 83-91

Setiawan, Aditya Toni \& Handayani, Dwi (2017). Model Pembelajaran Berbasis Permainan Tradisional Ancak-Ancak Alissebagai Pewmerkuat Karakter Bangsa di Era AEC: Prosiding eminar Nasional Pendidikan, 2(4), 58-71

Surat Keputusan Bersama Menteri Pendidikan dan Kebudayaan, Menteri Kesehatan, Menteri Agama dan Menteri Dalam Negeri Republik Indonesia Tahun 2020 tentang Penyelenggaraan Pembelajaran Tahun Pembelajaran 2020/2021 di Masa Pandemi Covid-19

Sugini, E \& Basit, A (2020).Pengaruh Media Pembelajaran berbasis AnimasiTerhadap Minat Belajar Peserta Didik kelas VII SMP IslamAllimudin Kabupaten Probolingg.Jurnal Ilmiah Mimbar Demokrasi, 19 (2), 28-31

Fiah, Eifda El \& Purbaya, Adi Putra. (2016). Penerapan Bimbingan Belajar dalam Meningkatkan Hasil Belajar Peserta Didik di SMP Negeri 12 Kota Bandar Lampung Tahun Pelajaran 2015/2016: Jurnal Bimbingan dan Konseling, 3(2), 171-184.

Munawwarah, R.A, (2019). Sparkol Videocribe sebagai Media Pembelajaran. EJournal UIN: Jurnal Inspiratif Pendidikan, 8(2), 430-437. 